\title{
Analisis Keunggulan Komparatif Sektor Peternakan Di Kabupaten Hulu Sungai Utara
}

\section{(Comparative Advantage Analysis of Livestock Sector in Hulu Sungai Utara Regency)}

\author{
Heldawati $^{1)}$ \& Siti Maisyarah ${ }^{2)}$ \\ Program Studi Agribisnis, Sekolah Tinggi Ilmu Pertanian Amuntai \\ ${ }^{1)}$ heldawati006@gmail.com \\ ${ }^{2)}$ mysa@gmail.com
}

\begin{abstract}
ABSTRAK
Penelitian ini bertujuan untuk membahas penerapan metode Location Quotient $(L Q)$ dalam mengidentifikasi komoditas unggulan sektor peternakan masing-masing kecamatan di Kabupaten Hulu Sungai Utara. Metode penelitian yang digunakan adalah metode penelitian deskriptif kuantitatif, data yang dikumpulkan dalam penelitian ini adalah data sekunder, penelitian ini akan mengidentifikasi dan menganalisis sektor komoditas unggulan atau basis peternakan. Analisis data menggunakan metode Location Quotient. Hasil penelitian menunjukkan bahwa populasi ternak dikatakan unggulan atau basis apabila memenuhi kriteria komoditas basis. Komoditas unggulan sektor peternakan di Kabupaten Hulu Sungai Utara meliputi ternak kerbau dan itik di Kecamatan Paminggir.
\end{abstract}

Kata Kunci: Metode, komoditas, penelitian, unggulan, ternak.

\section{ABSTRACT}

This study aims to discuss the application of Location Quotient $(L Q)$ method in identifying superior commodities of livestock sector of each sub-district in Hulu Sungai Utara Regency. The research method used is descriptive quantitative research method, the data collected in this research is secondary data, this research will identify and analyze superior commodity sector or livestock base. Data analysis using Location Quotient method. The results showed that the livestock population is said to be superior or base if it meets the criteria of basic commodities. Leading commodities of the livestock sector in Hulu Sungai Utara Regency cover buffalo cattle and ducks in Paminggir District.

Keywords: Methods, commodities, research, excellence, livestock.

\section{PENDAHULUAN}

Peternakan di Kabupaten Hulu Sungai Utara memiliki potensi yang sangat besar untuk dikembangkan, terutama itik Alabio dan kerbau rawa yang merupakan plasma nutfah daerah dan telah diusahakan masyarakat secara turun-temurun. Kawasan budidaya peternakan berupa pengembangan kawasan peruntukan peternakan seluas kurang lebih 576 ha, meliputi: ternak besar yang terdiri dari pengembangan daerah pusat pembibitan ternak sapi di Kecamatan Banjang dan pengembangan daerah pusat pembibitan ternak kerbau kalang atau kerbau rawa di Kecamatan Paminggir, dan ternak unggas yang terdiri dari pengembangan daerah pusat pemurnian ternak itik Alabio di Kecamatan Amuntai Selatan, pengembangan pakan alami untuk ternak unggas, dan pengembangan kawasan peternakan itik
Alabio dilakukan peternak di hampir seluruh kabupaten, namun sentra untuk peternakan itik Alabio terdapat di Kecamatan Amuntai Selatan, Babirik dan Danau Panggang (BPS Kab. HSU, 2017).

Berbagai pendekatan dan alat analisis telah banyak digunakan untuk mengidentifikasi komoditas unggulan, menggunakan beberapa kriteria teknis dan non teknis dalam kerangka memenuhi aspek penawaran dan permintaan. Setiap pendekatan memiliki kelebihan dan kelemahan, sehingga dalam memilih metode analisis untuk menentukan komoditas unggulan ini perlu dilakukan secara hati-hati dan bijaksana. Salah satu analisis untuk mengetahui komoditas unggulan adalah analisis location quotient (LQ). Location quotient adalah suatu metode untuk menghitung perbandingan relatif sumbangan nilai tambah sebuah sektor di suatu daerah 
(Kabupaten/Kota) terhadap sumbangan nilai tambah sektor yang bersangkutan dalam skala provinsi atau nasional (Hendayana, 2003). Ada beberapa keunggulan dari metode LQ, antara lain (1). Metode LQ memperhitungkan ekspor langsung dan ekspor tidak langsung (2). Metode LQ sederhana dan tidak mahal serta dapat diterapkan pada data historis untuk mengetahui trend. Beberapa kelemahan Metode LQ adalah (1). Berasumsi bahwa pola permintaan di setiap daerah identik dengan pola permintaan bangsa dan bahwa produktivitas tiap pekerja di setiap sektor regional sama dengan produktivitas tiap pekerja dalam industriindustri nasional. (2). Berasumsi bahwa tingkat ekspor tergantung pada tingkat disagregasi (Bappenas RI, 2017).

Tujuan penelitian adalah (i) mengetahui nilai LQ masing-masing kecamatan di Kabupaten Hulu Sungai Utara (ii) mengetahui komoditas Basis Peternakan di Kabupaten Hulu Sungai Utara.

\section{METODE PENELITIAN}

\section{Tempat dan Waktu Penelitian}

Waktu pelaksanaan penelitian ini dilaksanakan pada bulan Februari - Agustus 2017, sedangkan tempat penelitian adalah wilayah Kabupaten Hulu Sungai Utara.

\section{Jenis dan Sumber Data}

Data yang dikumpulkan meliputi data sekunder dari Tahun 2012-2016 mengenai populasi peternakan Kabupaten Hulu Sungai Utara, populasi peternakan per kecamatan yang bersumber dari Badan Pusat Statistik Kabupaten Hulu Sungai Utara.

\section{Metode Pengumpulan Data}

Data yang dikumpulkan dalam penelitian ini adalah data sekunder penelitian ini akan mengidentifikasi dan menganalisis sektor komoditas unggulan/basis peternakan. Jenis metode ini adalah yang digunakan untuk pengumpulan data, karena data yang diperlukan berupa data sekunder, yakni berbentuk laporan-laporan yang telah disusun oleh instansi terkait dalam pemerintahan Kabupaten Hulu Sungai Utara.

\section{Metode Penelitian}

Metode penelitian yang digunakan ini adalah deskriptif kuantitatif. Deskriptif kuantitatif adalah data yang diperoleh dari sampel populasi penelitian dianalisis sesuai dengan metode statistik yang digunakan kemudian diinterprestasikan.

\section{Analisis Data}

Menjawab pertanyaan pertama mengetahui nilai LQ masing-masing kecamatan di Kabupaten Hulu Sungai Utara. Adapun untuk mengetahui nilai LQ digunakan rumus;

$$
\mathrm{LQ}=\frac{p i / p t}{X i / X t}
$$

Dimana:

pi : Jumlah ternak per Kecamatan

pt : Jumlah seluruh ternak Kecamatan

$\mathrm{Xi}$ : Jumlah ternak Kabupaten Hulu Sungai Utara

Xt : Jumlah seluruh ternak Kabupaten Hulu Sungai Utara

Menjawab pertanyaan kedua mengetahui komoditas basis peternakan di Kabupaten Hulu Sungai Utara. Interprestasi komoditas basis LQ > 1 artinya komoditas itu menjadi basis atau menjadi sumber pertumbuhan, yang potensial secara komparatif dan memiliki keunggulan dan pengembangan peternakan. $\mathrm{LQ}=1$ artinya komoditas itu non basis atau tidak menjadi sumber pertumbuhan yang potensial secara komparatif dan hanya untuk memenuhi kebutuhan wilayah sendiri. LQ $<1$ artinya komoditas itu menjadi non basis atau tidak menjadi sumber pertumbuhan juga tidak mampu memenuhi kebutuhan pada wilayah sendiri (Robinson, 2005).

\section{HASIL DAN PEMBAHASAN}

\section{Hasil}

Sektor peternakan di Kabupaten Hulu Sungai Utara yaitu ternak besar, ternak kecil, dan ternak unggas yang meliputi sapi, kerbau, kambing, domba, ayam ras pedaging, ayam buras dan itik. Nilai Location Quotient (LQ) di Kabupaten Hulu Sungai Utara yang terbagi 
8 kecamatan berdasarkan tingkat populasi ternak sapi tersaji pada Gambar 1.

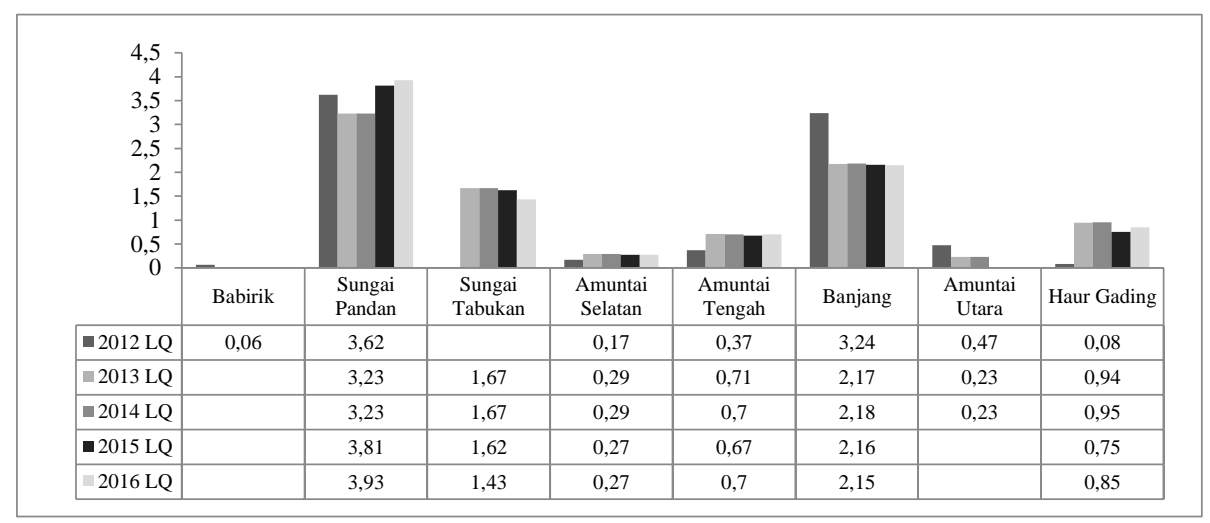

Gambar 1 diatas mengacu pada nilai LQ tertinggi selama 5 tahun berturut-turut ternak sapi maka, Kecamatan Sungai Pandan yang paling tinggi nilai LQ nya adalah Tahun 2012 LQ 3,61, Tahun 2013 LQ 3,23, Tahun 2014 LQ 3,23, Tahun 2015 LQ 3,81 dan Tahun 2016 LQ 3,93.
Gambar 2 mengacu pada nilai LQ tertinggi selama 5 tahun berturut-turut ternak kerbau, maka Kecamatan Paminggir yang paling tinggi niali LQ nya adalah Tahun 2012 LQ 1,34, Tahun 2013 LQ 0,94, Tahun 2014 LQ 0,45, Tahun 2015 LQ 1,01, dan Tahun 2016 LQ $1,79$.
Gambar 2. Quotient (LQ)

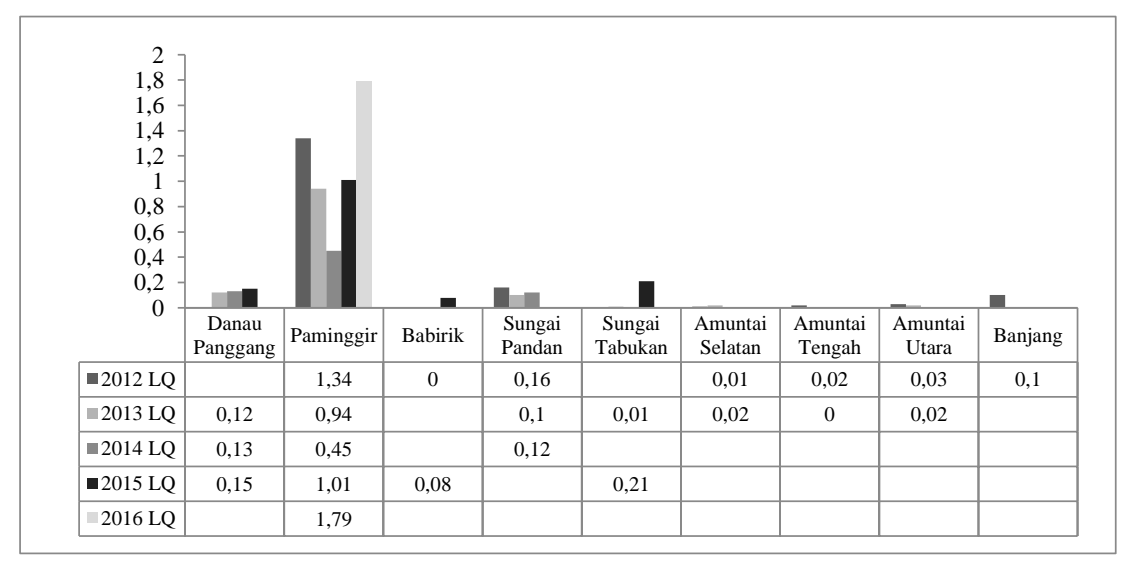

2012-2016
Nilai Location Kerbau Tahun

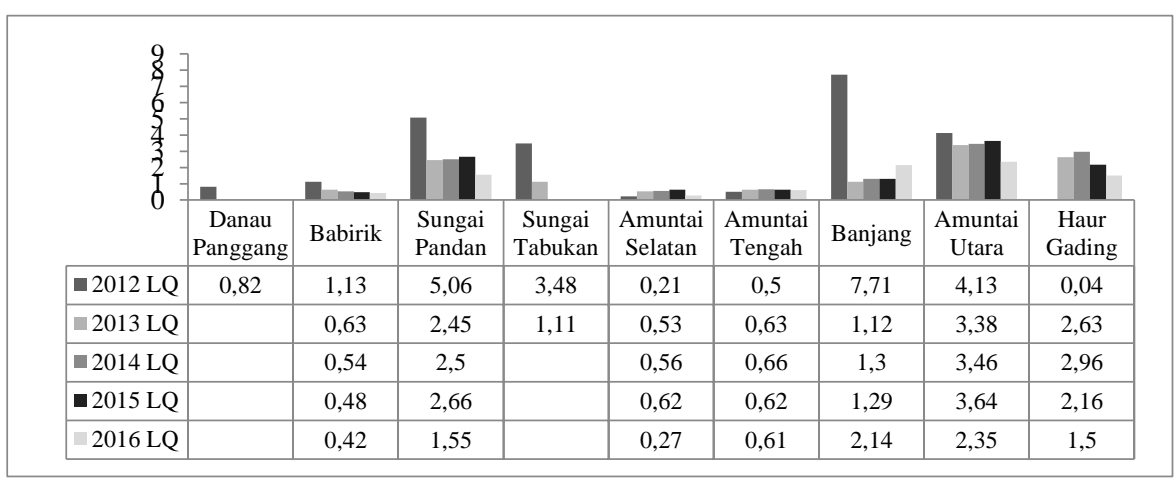

Gambar 3. Nilai Location Quotient (LQ) Kambing Tahun 2012-2016 
Gambar 3 mengacu pada nilai LQ tertinggi selama 5 tahun berturut-turut ternak kambing, maka Kecamatan Banjang yang paling tinggi niali LQ nya adalah Tahun 2012
LQ 7,71, Tahun 2013 LQ 1,12, Tahun 2014

LQ 1,30, Tahun 2015 LQ 1,29 dan Tahun 2016 LQ 2,14.

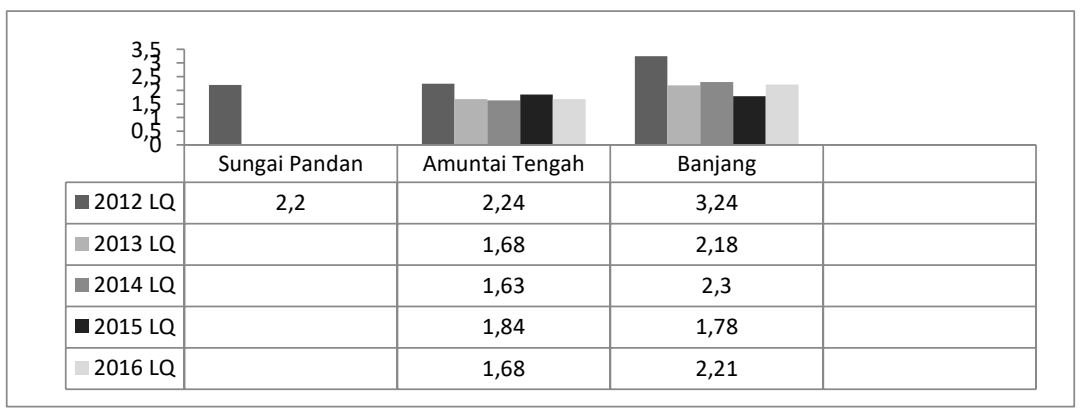

Gambar 4. Nilai Location Quotient (LQ) Domba Tahun 2012-2016

Gambar 4 mengacu pada nilai LQ tertinggi selama 5 tahun berturut-turut ternak domba, maka Kecamatan Banjang yang paling tinggi nilai LQ nya adalah Tahun 2012
LQ 3,24, Tahun 2013 LQ 2,18, Tahun 2014 LQ 2,3, Tahun 2015 LQ 1,78 dan Tahun 2016 LQ 2,2.

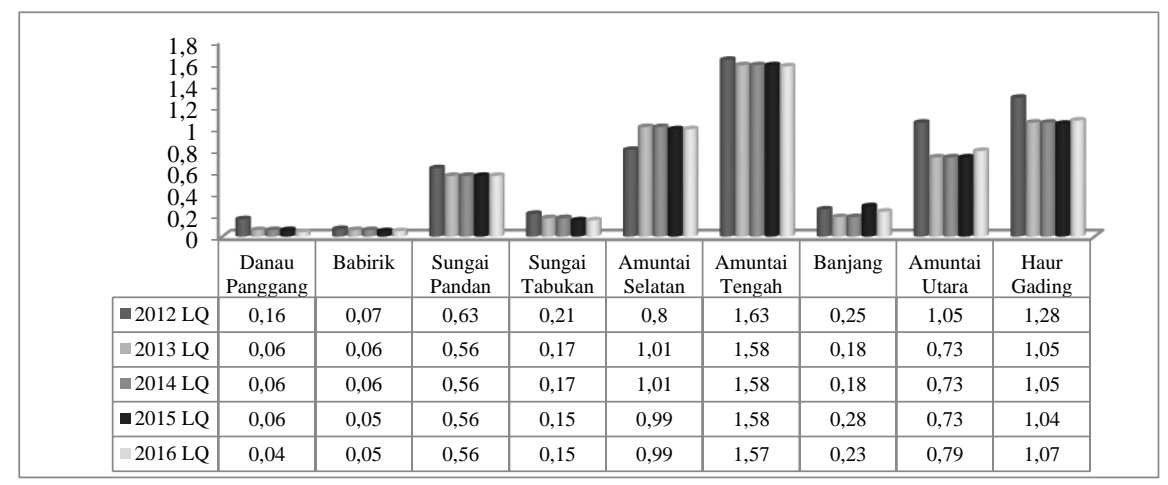

Gambar 5. Nilai Location Quotient (LQ) Ayam Ras Pedaging Tahun 2012-2016

Gambar 5 mengacu pada nilai LQ tertinggi selama 5 tahun berturut-turut ternak ayam ras pedaging, maka Kecamatan Amuntai Tengah yang paling tinggi nilai LQ nya adalah Tahun 2012 LQ 1,63, Tahun 2013 LQ 1,58, Tahun 2014 LQ 1,58, Tahun 2015 LQ 1,58, dan Tahun 2016 LQ 1,57 .

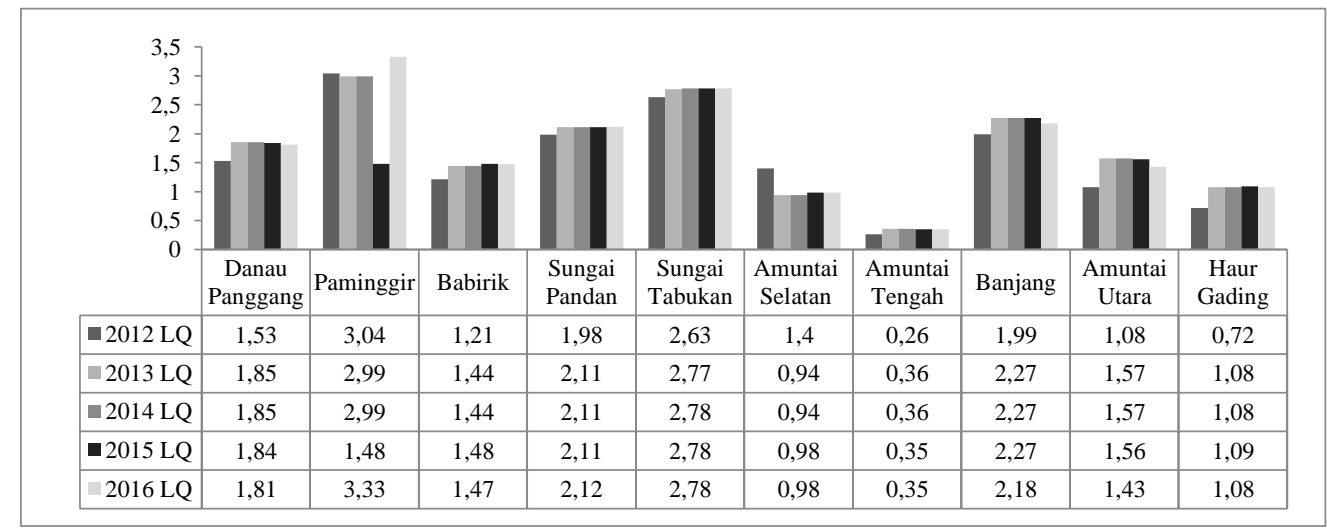

Gambar 6. Nilai Location Quotient (LQ) Ayam Buras Tahun 2012-2016 
Gambar 6 mengacu pada nilai LQ tertinggi selama 5 tahun berturut-turut ternak ayam buras, maka Kecamatan Amuntai Tengah yang paling tinggi nilai LQ nya adalah Tahun 2014 LQ 4,85.

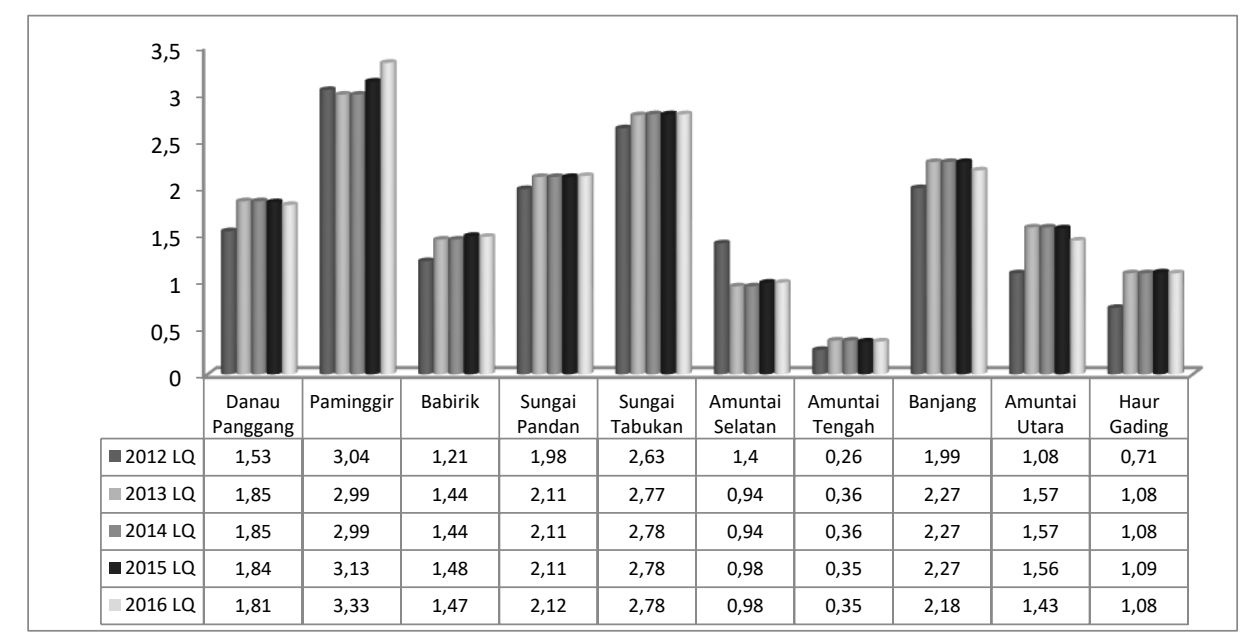

Gambar 7. Nilai Location Quotient (LQ) Itik Tahun 2012-2016

Gambar 7 mengacu pada nilai LQ tertinggi selama 5 tahun berturut-turut ternak ayam buras, maka Kecamatan Amuntai Tengah yang paling tinggi nilai LQ nya adalah Tahun 2012 LQ 3,04, Tahun 2013 LQ 2,99, Tahun 2014 LQ 2,99, Tahun 2015 LQ 3,13 dan Tahun 2016 LQ 3,33.

\section{Pembahasan}

Jumlah populasi ternak terbesar di Kabupaten Hulu Sungai Utara adalah Kecamatan Paminggir, yaitu ternak Kerbau dan Itik. Nilai LQ > 1 untuk ternak sapi dari tahun (2012-2016) terdapat pada 3 kecamatan ,kerbau terdapat 1 kecamatan nilai LQ > 1, kambing terdapat 6 kecamatan nilai LQ > 1, domba terdapat 3 kecamatan nilai LQ $>1$, ayam ras pedaging terdapat 3 kecamatan nilai LQ > 1, ayam buras terdapat 9 kecamatan nilai $\mathrm{LQ}>1$, dan itik terdapat 9 kecamatan nilai $\mathrm{LQ}>1$.

\section{KESIMPULAN}

Nilai LQ peternakan > 1 masingmasing kecamatan di Kabupaten Hulu Sungai Utara adalah sebagai berikut: a. Kecamatan Sungai Pandan: sapi, kambing, domba, dan itik. b. Kecamatan Paminggir: kerbau. c. Kecamatan Amuntai Tengah: ayam ras pedaging, dan ayam buras. Komoditas basis di kabupaten Hulu Sungai Utara dengan LQ
$>$ 1, antara lain ternak Sapi di Kecamatan Sungai Pandan, ternak Kerbau di Kecamatan Paminggir, ternak Kambing di Kecamatan Banjang, ternak Domba di Kecamatan Banjang, ternak Ayam Ras Pedaging di Kecamatan Amuntai Tengah, ternak Ayam Buras di Kecamatan Amuntai Tengah, dan ternak Itik di Kecamatan Paminggir.

\section{DAFTAR PUSTAKA}

BPS Kab. HSU. 2017. Kabupaten HSU Dalam Angka Tahun 2016. Badan Pusat Statistik Kabupaten Hulu Sungai Utara. Amuntai.

Bappenas RI. 2017. Perangkat Analisis Untuk Perencanaan. https://www.bappenas.go.id. Di akses tanggal 4 Januari 2017.

Hendayana, R. 2003. Aplikasi metode Location Quotient (LQ) dalam penentuan komoditas unggulan nasional. Informatika Pertanian Volume 12 (Desember 2003).

Robinson, T. 2005. Ekonomi Regional Teori dan Aplikasi. PT. Bumi Angkasa. Jakarta. 